\title{
Formula Optimization of Annona muricata Folium Ethanolic Extract of Anti Acne Gel Formulation using Factorial Design Method
}

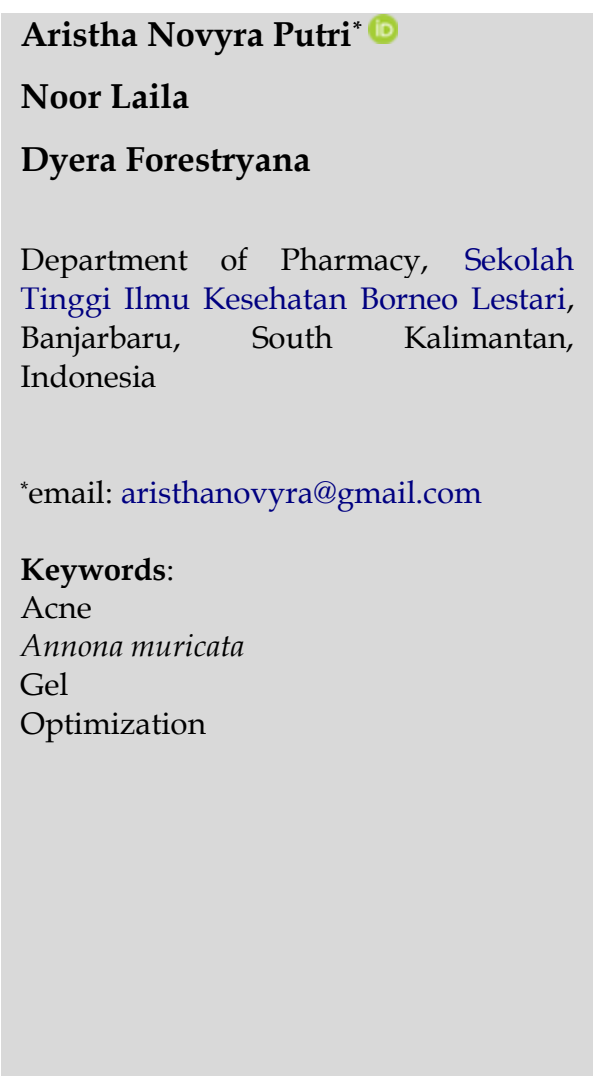

\begin{abstract}
Acne is a pile of oil glands in the skin that are actively being clogged by dirt and infection because of Propionibacterium acnes, Staphylococcus aureus, and Staphylococcus epidermidis. The treatment for acne can use herbal ingredients, one of which is Soursop (Annona muricata L.) leaves ethanolic extract. Annona muricata folium ethanolic extract is known to have alkaloid, flavonoid and polyphenol compounds which can inhibit the growth of P. acnes, S. epidermidis, and S. aureus. Suitable dosage forms for anti-acne preparations are gels because the gel contains much water so that it provides a cooling effect on the skin due to inflammation. The purpose of this study was to determine the impact of carbopol 940 and propylene glycol on the physical characteristics of the gel preparation and determine the optimum formula of the gel preparation using factorial design software 22 so that the gel preparation was made in four formulas. The data obtained were then analyzed using Design-Expert ${ }^{\circledR}$ and ANOVA software with a confidence level of $95 \%$, and the determination of the optimum formula based on the optimum superimposed contour plot area. The results of the study using a factorial design approach are known that propylene glycol has an effect on increasing the spreadability and $\mathrm{pH}$ while carbopol 940 has a more significant impact on the increase in adhesion and viscosity, and the optimum area of the composition of carbopol $9401.536 \%$ and propylene glycol 5\% was obtained.
\end{abstract}

Received: September $11^{\text {th }} 2019$

Accepted: October 31 th 2019

Published: November 14th 2019

(c) 2019 Aristha Novyra Putri, Noor Laila, Dyera Forestryana. Published by Institute for Research and Community Services Universitas Muhammadiyah Palangkaraya. This is an Open Access article under the CC-BY-SA License (http://creativecommons.org/licenses/by-sa/4.0/). DOI: https://doi.org/10.33084/bjop.v2i2.981.

\section{INTRODUCTION}

Acne is a very extreme form of inflammation that occurs in the skin due to a blockage in the pores because of the accumulation of oil. This inflammation is triggered by Propionibacterium acnes, Staphylococcus aureus, and Staphylococcus epidermidis bacteria (Achermann et al., 2014; Otto, 2009). Acne can be treated using ingredients from nature, the use of natural ingredients as active substances is believed to provide smaller side effects, so it is safe if used long term (Yang et al., 2017). Natural materials that can be used are in the treatment of acne, one of which is soursop or Annona muricata L. leaves. Ethanol extract of A. muricata leaves can inhibit the growth of P. acnes, $S$. aureus, and S. epidermidis bacteria with a concentration of $10 \%$ (Mulyanti et al., 2015). Soursop leaf ethanol extract is most effectively used as an anti-acne because it can inhibit the growth of bacteria with a low concentration (Pai et al., 2016).

The gel is a two-component, semi-solid system that contains much water. Gel preparations in the treatment of acne are excellent than other topical preparations because they contain more water (Chang et al., 2013). According to the research of Fujiastuti \& Sugihartini (2015), gels formulated using carbopol gelling agents have good physical properties and minimal irritation effect. In gel preparations, humectants are often added to 
improve consistency and increase the solubility of the ingredients. Humectant used is propylene glycol (Purnamawati et al., 2017).

The above description is the background of the researchers to optimize the determination of the optimum formula for the preparation of anti-acne gel ethanol extract 95\% soursop leaves using software Design-Expert ${ }^{\circledR}$ factorial 22 (2 factors two levels). This study aimed to determine the impact of carbopol 940 and propylene glycol on the physical characteristics of the gel preparation and determine the optimum formula of the gel preparation. The optimized factor is carbopol 940 (gelling agent) with propylene glycol (humectant). Optimization of the two factors was carried out to determine the effect of variations in the concentration of each factor on the response of adhesion, dispersion, $\mathrm{pH}$, and viscosity.

\section{MATERIALS AND METHODS}

\section{Tools and materials}

Materials used in this study include $\mathrm{Mg}, \mathrm{HCl}, \mathrm{FeCl} 3$, Dragendroff reagent, Mayer, extract, carbopol 940, aquadest, 95\% ethanol, PG, TEA, and methylparaben. While the tools used in this study include a funnel, scales, hot plate, mortar stamper, $\mathrm{pH}$ meter, test tube, rotary evaporator, and viscometer Stromer.

\section{Soursop leaves ethanol extract gel preparation}

Soursop leaf determination was carried out at the Faculty of Mathematics and Natural Sciences Basic Laboratory, Universitas Lambung Mangkurat. A total of $500 \mathrm{~g}$ of powder was put into a glass container, and $95 \%$ ethanol (1:10) was added. Stirring is then allowed to stand for 24 hours. After 24 hours, the filtering and re-maceration were carried out three times. Macerate is put together then concentrated using a rotary evaporator at a temperature of $50^{\circ} \mathrm{C}$ so that thick extracts are obtained and extract extraction is calculated, and phytochemical screening is alkaloid, flavonoid, and polyphenol (Mulyanti et al., 2015).

\section{Formulation of soursop leaves ethanol extract gel}

The method of making the gel, according to Pertiwi et al. (2016). Carbopol 940 was developed with hot water 20 times the weight of carbopol 940 while stirring until homogeneous. Triethanolamine and PG are added crushed until homogeneous. Mixed with extract and methyl parabens that have been dissolved with aquadest. The remaining aquadest was added and crushed until homogeneous. The test then conducted to evaluates gel preparations that have been made. The composition of the formula used is presented in Table I.

Table I. Formulation of soursop leaves ethanol extract gel

\begin{tabular}{lcccc}
\hline \multirow{2}{*}{ Composition } & \multicolumn{4}{c}{ Formula (\%) } \\
\cline { 2 - 5 } & I & II & III & IV \\
\hline Soursop leaves ethanol extract & 10 & 10 & 10 & 10 \\
Carbopol 940 & 0.5 & 0.5 & 2 & 2 \\
Propylene glycol & 5 & 10 & 5 & 10 \\
TEA & 2 & 2 & 2 & 2 \\
Methyl paraben & 0.1 & 0.1 & 0.1 & 0.1 \\
Aquadest ad & 100 & 100 & 100 & 100 \\
\hline Formula description: & & & \\
I = Carbopol 940: Propylene glycol $(0.5 \%: 5 \%)$ & & & \\
II $\quad=$ Carbopol 940: Propylene glycol $(0.5 \%: 10 \%)$ & & & \\
III = Carbopol 940: Propylene glycol $(2 \%: 5 \%)$ & & & \\
IV = Carbopol 940: Propylene glycol $(2 \%: 10 \%)$ &
\end{tabular}

\section{Evaluation of soursop leaves ethanol extract gel}

Organoleptic test

Observation of the shape, color, and odor of the gel, note the results obtained. The observation is replicated three times. The gel is usually clear with a semi-solid consistency with smell and color depending on the excipient used (Ansel, 1989).

\section{Homogeneity test}

The gel is applied to a piece of transparent glass, observing the results obtained. The observation is replicated three times. The preparation must show homogeneous visuals without any lumps insight (Sayuti, 2015). 
pH test

The $\mathrm{pH}$ meter was dipped into the gel, and the $\mathrm{pH}$ obtained is observed. The observation is replicated three times. The $\mathrm{pH}$ requirements for gel preparation are in the range of 4.5-6.5 (Daud et al., 2018).

\section{Stickiness test}

As much as $0.25 \mathrm{~g}$ gel is placed between two glass objects, then $1 \mathrm{~kg}$ load is pressed for five minutes, the load is lifted, and $80 \mathrm{~g}$ is loaded on the instrument and the gel release time is recorded. The observation is replicated three times, where good adhesion indicated by release time more than 1 second (Afianti \& Murrukmihadi, 2015)

\section{Scattering test}

As much as $0.5 \mathrm{~g}$ gel is placed in the middle on top of the gel and another transparent round glass and ballast so that the weight of the glass and the ballast are $150 \mathrm{~g}$, allowed to stand for 1 minute, then the distribution diameter is recorded. The observation is replicated three times (Sayuti, 2015).

\section{Viscosity test}

Viscosity test was conducted using Stromer viscometer. The gel is put into a container and then installed a spindle, the spindle must be submerged in the gel. The viscometer is turned on with a $60 \mathrm{rpm}$. Viscosity results were observed. The observation is replicated three times. Proper viscosity is between the range of 3,000-50,000 cPs (Pertiwi et al., 2016).

\section{Acceptability test}

Acceptability test was conducted using a questionnaire. As much as 20 volunteers were asked to respond to the color, aroma, and texture of the gel with a score of 1 to 4 assessment feeling very like, like, less like, and dislike (Sayuti, 2015).

\section{Data analysis}

Data obtained from the results of the test of stickiness, scattering, $\mathrm{pH}$ and viscosity were analyzed using Design-
Expert $^{\circledR}$ software and ANOVA with a 95\% confidence level (Astuti et al., 2017). Determination of the optimum formula was determined based on ANOVA and superimposed contour plot of the parameters of adhesion, dispersion, $\mathrm{pH}$ and viscosity of ethanol extracts of soursop with variations in the concentration of carbopol 940 gelling agent and humectant propylene glycol (Aulena et al., 2016).

\section{RESULTS AND DISCUSSION}

Soursop leaf powder is extracted using the cold maceration method. The solvent used was 95\% ethanol, with a ratio of 1 : 10 (Handayani et al., 2016). The use of 95\% ethanol solvent is intended to attract non-polar and polar compounds. The extraction process does not use water solvents, because it is difficult to evaporate at low temperatures and requires a long time, so the extracts produced have the potential to have high water content and are prone to fungal growth as a result of lowering the quality (Ministry of Health of the Republic of Indonesia, 1995). The ethanol solvent is used because it is safe, nontoxic, and more effortless in the concentration process because it requires less heat for the concentration process and microbes are more difficult to grow (Chemat et al., 2019). Maceration is carried out for four days, and every 24 hours, a mass filtering is done. The extract yield obtained was $16.48 \%$ with a $\mathrm{pH}$ of 6.1 .

After the thick extract is obtained, then phytochemical screening was performed. The purpose of phytochemical screening is to ensure the presence of chemical compounds that are indicated as antibacterial, including alkaloids, flavonoids, and polyphenols (Andriani et al., 2015). Phytochemical screening results showed flavonoids and polyphenols, while alkaloid tests showed positive results with the Mayer reagent. The results of the phytochemical screening are presented in Table II. 
Table II. Phytochemical screening results of soursop leaves ethanol extract gel

\begin{tabular}{lllc}
\hline Compounds & Reagent & \multicolumn{1}{c}{ Result } & Conclusion \\
\hline Flavonoid & Wilstatter & $\begin{array}{l}\text { Reddish red } \\
\text { color } \\
\text { The absence } \\
\text { of red } \\
\text { deposits }\end{array}$ & + \\
& Dragendorff & - \\
Polyphenol & $\mathrm{FeCl}_{3}$ & $\begin{array}{l}\text { White } \\
\text { precipitate } \\
\text { Blackish } \\
\text { green }\end{array}$ & + \\
\hline
\end{tabular}

Gel preparations in the treatment of acne are excellent than other topical preparations because they contain more water, have a good appearance and are able to provide high speed in the release of drugs and absorption in skin treatment so that the gel preparations are suitable for the treatment of acne (Marriott et al., 2010). The dosage form made in this research is a hydrogel. The hydrogel is chosen because it has a proper drug release and provides a cooling effect and is easily washed with water (Yang et al., 2018). The ethanol extract gel of soursop leaves was made using carbopol 940 bases as a gelling agent and propylene glycol as a humectant which was optimized using low concentrations and high concentrations. The visual appearance of the gel that has been made from each formula is presented in Figure 1.

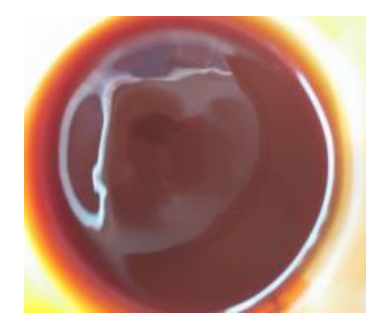

a

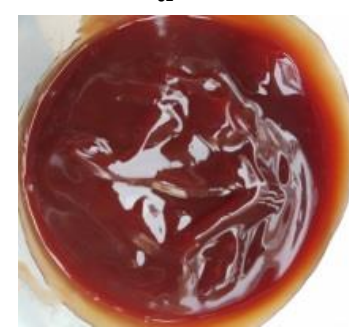

C

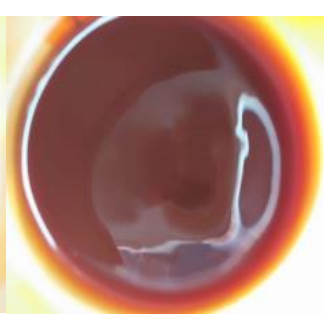

b

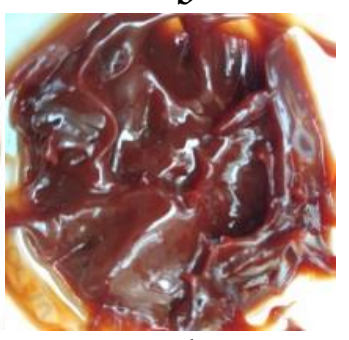

d
Figure 1. Soursop leaf ethanol extract gel of Formula I (a), Formula II (b), Formula III (c), and Formula IV (d)

Test evaluation was conducted to observe the quality of preparations and ensure that this preparation has characteristics that are following the specified physical properties. Evaluation of the determined test consisted of organoleptic, homogeneity, $\mathrm{pH}$, stickiness, scattering, viscosity, and acceptability test by the respondent. Complete results of the evaluation test are presented in Table III.

Table III. Evaluation of soursop leaves ethanol extract gel

\begin{tabular}{|c|c|c|c|c|c|c|}
\hline$\frac{\pi}{3}$ & $\begin{array}{l}\stackrel{D}{0} \\
\stackrel{0}{0} \\
0 \\
0\end{array}$ & 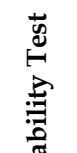 & 楶 & Dै & 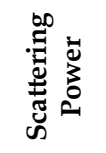 & 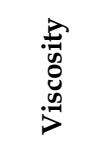 \\
\hline II & 节 & 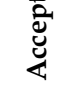 & & $\begin{array}{c}\text { (s) } \pm \\
\text { SD }\end{array}$ & $\begin{array}{c}(\mathrm{cm} \\
\mathrm{g} / \mathrm{s}) \pm \\
\mathrm{SD}\end{array}$ & $\begin{array}{c}\text { (cPs) } \pm \\
\text { SD }\end{array}$ \\
\hline I & Homogen & $\begin{array}{l}\text { Less } \\
\text { like }\end{array}$ & 6.5 & $\begin{array}{c}51 \pm \\
0.5\end{array}$ & $\begin{array}{c}19.33 \pm \\
0.6\end{array}$ & $\begin{array}{c}1,767 \pm \\
5.7\end{array}$ \\
\hline II & Homogen & Like & 6.4 & $\begin{array}{c}53 \pm \\
1\end{array}$ & $\begin{array}{c}14.58 \pm \\
0.1\end{array}$ & $\begin{array}{c}3,766 \pm \\
5.7\end{array}$ \\
\hline III & Homogen & $\begin{array}{l}\text { Less } \\
\text { like }\end{array}$ & 5.3 & $\begin{array}{c}56 \pm \\
0.5\end{array}$ & $\begin{array}{c}12.58 \pm \\
0.1\end{array}$ & $\begin{array}{c}8,447 \pm \\
5.7\end{array}$ \\
\hline IV & Homogen & $\begin{array}{l}\text { Less } \\
\text { like }\end{array}$ & 5.7 & $\begin{array}{c}59 \pm \\
0.5\end{array}$ & $\begin{array}{c}11.58 \pm \\
0.1\end{array}$ & $\begin{array}{c}9,583 \pm \\
5.7\end{array}$ \\
\hline
\end{tabular}

Organoleptic test evaluation aims to determine the nature of the gel-based on observations by the sense of sight and smell (Dantas et al., 2016). Organoleptic test results of gel preparations that have a distinctive odor of extract with a brown color. Homogeneity test describes the formation of particles that are not separated or evenly prepared from all components. Homogeneity test aims to look at the mixture of ingredients in a gel preparation that shows a homogeneous visual so that when applied to the skin, there are no coarse grains. Homogeneity examination of soursop leaf extract gel preparations in the four formulas in Table III showed the preparation did not show any coarse grains when the preparation was applied to transparent glass (Dantas et al., 2016). Acceptability test is performed to find out whether consumers (people) are interested in the formulated preparations. The results of the favored test conducted on 20 volunteers using anti-acne gel showed that Formula II was preferred over other formulas, as shown in Table III where the average respondent less likes the formula 
made except in Formula II, the average respondent likes it.

The $\mathrm{pH}$ test aims to determine the $\mathrm{pH}$ of each formula made. Gel with too acidic $\mathrm{pH}$ can irritate the skin while gel that is too alkaline can make the skin dry so the preparation must have a $\mathrm{pH}$ that matches the skin. Table III shows that in the four formulas, the skin $\mathrm{pH}$ range is 4.5-6.5, which is fulfill the requirement of $\mathrm{pH}$ for gel preparation (Daud et al., 2018). Based on the approach using the factorial design method, the equation $Y=5.97$ $0.475 \mathrm{~A}+0.075 \mathrm{~B}+0.125 \mathrm{AB}$, where $\mathrm{Y}=\mathrm{pH}$ response; $\mathrm{A}=$ carbopol 940; $\mathrm{B}=$ propylene glycol; $\mathrm{AB}=$ Interaction of the two factors and contour plot in response to $\mathrm{pH}$ are presented in Figure 2. Based on the equation and contour plot shows that carbopol 940 can reduce the $\mathrm{pH}$ aimed at the coefficient value of the negative equation $(-0.475)$, but propylene glycol alone and the interaction of carbopol 940 with propylene glycol can increase the $\mathrm{pH}$ of the gel. The more carbopol 940, the lower the $\mathrm{pH}$ because the number of acid groups contained in carbopol 940 is 2-3 (Andini et al., 2017). Whereas the more propylene glycol, the more alkaline it is so that the high $\mathrm{pH}$. This is consistent with Rowe et al. (2009) that propylene glycol is alkaline with $\mathrm{pH}>7.5$.

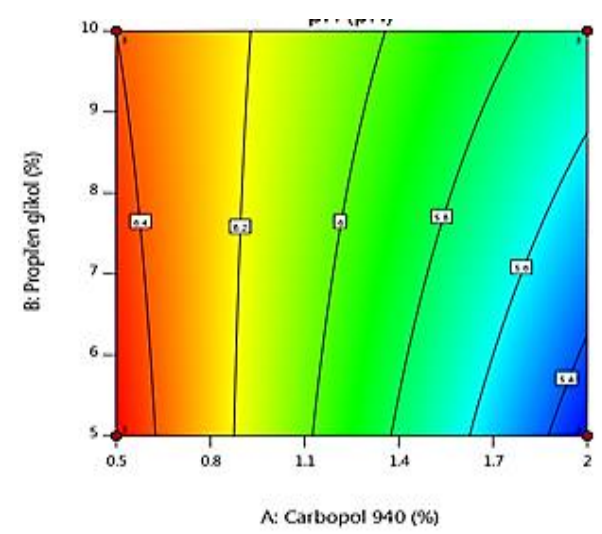

Figure 2. Contour plot for $\mathrm{pH}$ of soursop leaves ethanol extract gel

Stickiness test was performed to show the ability of the adhesive to adhere and cover the surface of the skin when used in order to function optimally. The longer the gel is attached to the skin, the better the gel is produced because it can increase the release of active substances and then penetrate the skin to provide a therapeutic effect (Prausnitz \& Langer, 2008). There are no specific requirements regarding the adhesion of semisolid solid preparations, but it should be the adhesion of semisolid solids is more than 1 second (Afianti \& Murrukmihadi, 2015). Table III shows that the value of adhesion in Formula I to Formula IV is between 51 to 59 seconds, which means the preparation has met the minimum requirements for adhesion. Based on the approach using the factorial design method, the equation $Y=55+2.83 \mathrm{~A}$ $+1.17 \mathrm{~B}+0.3333 \mathrm{AB}$, where $\mathrm{Y}=$ the adhesive response; $\mathrm{A}$ $=$ carbopol 940; $\mathrm{B}=$ propylene glycol; $\mathrm{AB}=$ Interaction of both factors and contour plot in response to stickiness are presented in Figure 3. Based on the equation and contour plot shows that carbopol 940, propylene glycol, and the interaction of carbopol 940 and propylene glycol can increase adhesion. Carbopol 940 is able to form colloids by the addition of hot water which is formed because the dispersing agent absorbs the dispersing medium so that it becomes thick and sticky, therefore the higher the carbopol 940, the more colloidal formed will be and be able to increase its stickiness (Rowe et al., 2009).

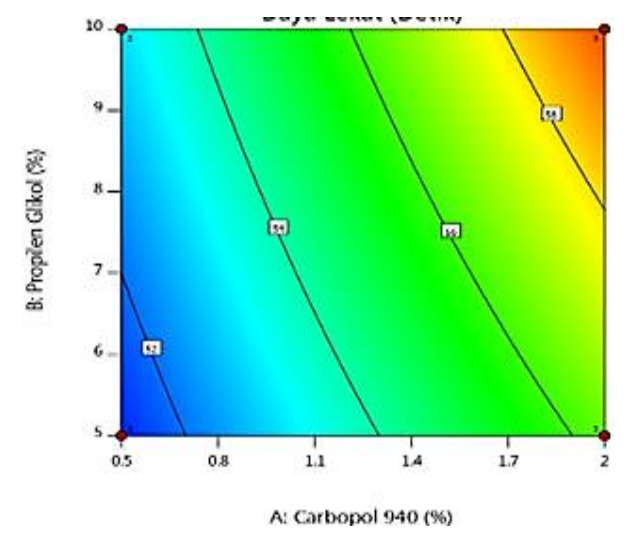

Figure 3. Contour plot for the stickiness of soursop leaves ethanol extract gel

The scattering test shows the ability of the preparation to spread when it is applied to the skin. The purpose of the spread test is to ensure even distribution of the gel when 
applied to the skin. Scattering power is inversely proportional to viscosity, where the higher the viscosity, the lower the spread power produced and vice versa (Dantas et al., 2016). Table III shows that Formula 1 has the highest spreadability shown by the spread power value of $19.33 \mathrm{~cm} . \mathrm{g} / \mathrm{s}$, wherein every second, Formula 1 can spread as much as $19.33 \mathrm{~cm}$ per 1 gram of load. Based on the results of the approach using the factorial design method, an equation is obtained, namely $\mathrm{Y}=14.52-1.44 \mathrm{~A}$ $-2.44 \mathrm{~B}+0.9375 \mathrm{AB}$, where $\mathrm{Y}=$ the spread response; $\mathrm{A}=$ carbopol 940; B = propylene glycol; AB = Interaction of two factors and contour plot graph are presented in Figure 4. Based on the equation and contour plot shows that the addition of carbopol reduces the spreadability, this is because carbopol 940 has a high viscosity so that the bond gets stronger which causes the distribution diameter to decrease and vice versa (Rowe et al., 2009).

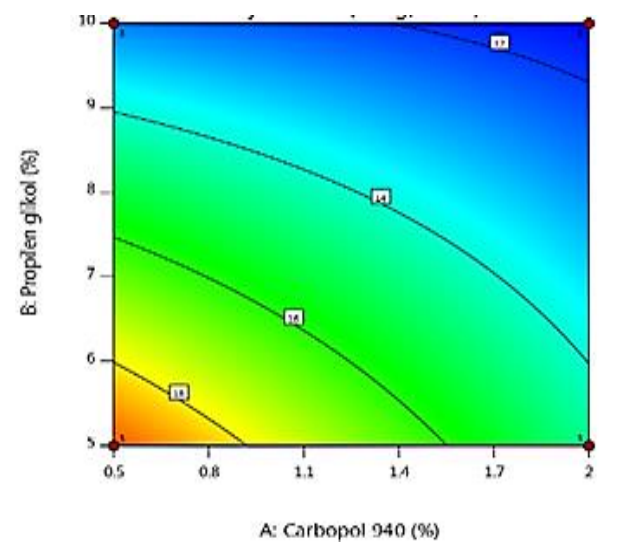

Figure 4. Contour plot for the scattering of soursop leaves ethanol extract gel

Viscosity is a statement of the resistance of a liquid to flow, in which the higher the viscosity, the higher the resistance (Pertiwi et al., 2016). The viscosity test result data in Table III shows that Formula 2 until Formula 4 has fulfilled the viscosity test requirements except for Formula 1. Based on the results of the approach using the factorial design method, an equation is obtained, namely $\mathrm{Y}=5890.83+3124.17 \mathrm{~A}+784.17 \mathrm{~B}-215.83 \mathrm{AB}$, where $\mathrm{Y}=$ viscosity response; $\mathrm{A}=$ carbopol 940; $\mathrm{B}=$ propylene glycol; $\mathrm{AB}=$ Interaction of two factors and viscosity plot contour plot graph are presented in Figure 5. Based on the equation and contour plot graph shows that the interaction between carbopol and propylene glycol further increases the viscosity response. This is because propylene glycol can maintain the water content in the preparation to improve consistency and increase the solubility of the material so that propylene glycol can reduce the viscosity of carbopol 940 (Rowe et al., 2009).

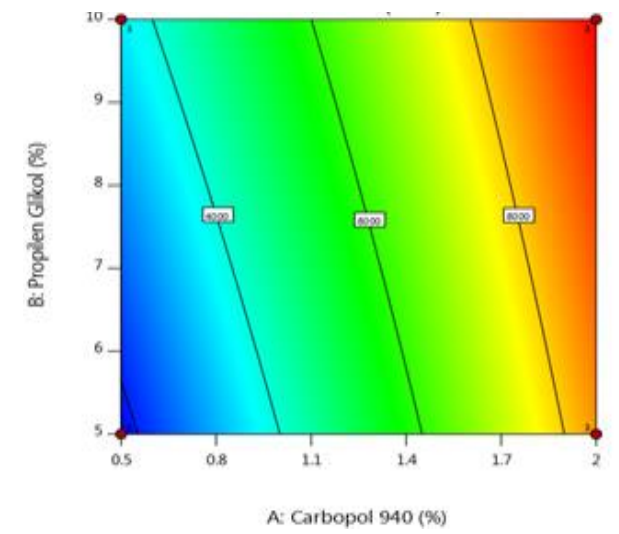

Figure 5. Contour plot for the viscosity of soursop leaves ethanol extract gel

Determination of the optimum formula for the preparation of soursop leaves ethanol extract gel using Software Design-Expert ${ }^{\circledR}$ version 11 with parameters including $\mathrm{pH}$, stickiness, viscosity, and scattering. Formula optimization is done after the mathematical equation model is obtained from each parameter. The results of the analysis of testing each response produce a Superimposed Contour Plot or Overlay Plot (data union) can be seen in Figure 6. Based on the superimposed contour plot, the yellow area is the optimum region with the physical properties of the gel that has fulfilled the specified requirements, which sets the optimum formula of ethanol extract of soursop leaves on the composition of carbopol $9401.536 \%$ and propylene glycol 5\%. 


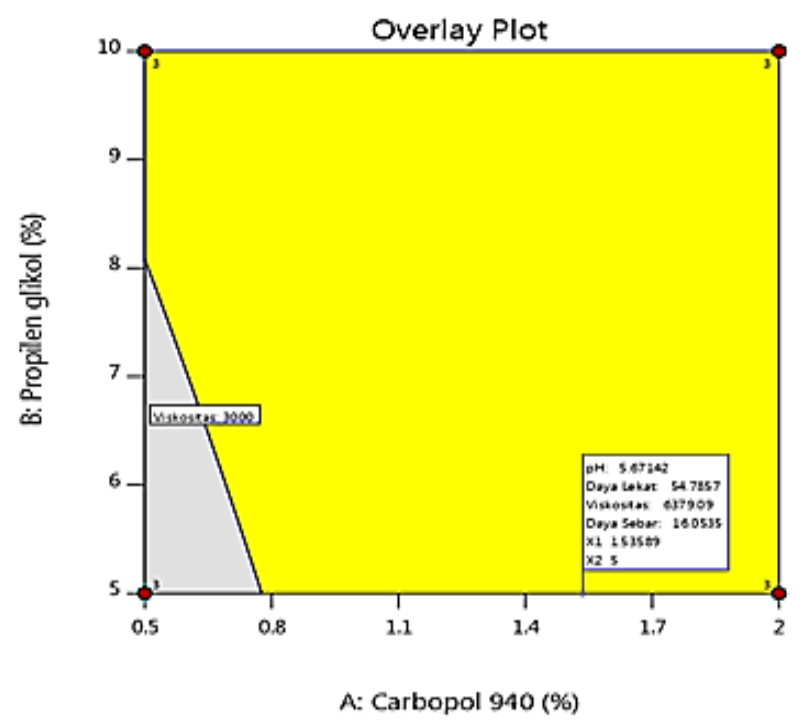

Figure 6. Superimposed contour plot optimum parameters of soursop leaves ethanol extract gel

\section{CONCLUSION}

The optimum formula for soursop leaves ethanol extract gel with the composition of gelling agent carbopol 940 $1.536 \%$ and humectant propylene glycol 5\% was obtained.

\section{ACKNOWLEDGMENT}

This work was supported by Sekolah Tinggi Kesehatan Borneo Lestari Banjarbaru.

\section{REFERENCES}

Achermann, Y., Goldstein, E.J.C., Coenye, T., Shirtliff, M.E. 2014. Propionibacterium acnes: from Commensal to Opportunistic BiofilmAssociated Implant Pathogen. Clinical Microbiology Reviews. 27(3):419-440. https://dx.doi.org/10.1128/CMR.00092-13

Afianti, H.P., Murrukmihadi, M. 2015. Pengaruh Variasi Kadar Gelling Agent HPMC terhadap Sifat Fisik dan Aktivitas Antibakteri Sediaan Gel Ekstrak Etanolik Daun Kemangi (Ocimum basilicum L. forma citratum Back.). Majalah Farmaseutik. 11(2):307-315. https://doi.org/10.22146/farmaseutik.v11i2. 24121
Andini, T., Yusriadi, Yuliet. 2017. Optimasi Pembentuk Film Polivinil Alkohol dan Humektan Propilen Glikol pada Formula Masker Gel Peel off Sari Buah Labu Kuning (Cucurbita moschata Duchesne) sebagai Antioksidan. Jurnal Farmasi Galenika (Galenika Journal of Pharmacy).

3(2):165-173. http://dx.doi.org/10.22487/j24428744.0.v0.i0. 8773

Andriani, Y., Ramli, N.M., Syamsumir, D.F., Kassim, M.N.I., Jaafar, J., Aziz, N.A., Marlina, L., Musa, N.S., Mohamad, H. 2015. Phytochemical analysis, antioxidant, antibacterial and cytotoxicity properties of keys and cores part of Pandanus tectorius fruits. Arabian Journal of Chemistry. In Press:1-10. https://doi.org/10.1016/j.arabjc.2015.11.003

Ansel, H. 1989. Pengantar Bentuk Sediaan Farmasi Edisi Keempat. Jakarta: Universitas Indonesia Press.

Astuti, D.P., Husni, P., Hartono, K. 2017. Formulasi dan Uji Stabilitas Fisik Sediaan Gel Antiseptik Tangan Minyak Atsiri Bunga Lavender (Lavandula angustifolia Miller). Farmaka. 15(1):176-184. https://doi.org/10.24198/jf.v15i1.13252.g613 2

Aulena, D.N., Purba, A.V., Djamil, R. 2016. Formulation and Evaluation of Gel Contains the Combination of Ethanol Extract Basil leaves (Ocimum sanctum L.) and Soursop Leaves (Annona muricata L.) as a Mosquito Repellent. International Journal of Pharmacy and Pharmaceutical Research. 7(2):10-18.

Chang, R.K., Raw, A., Lionberger, R., Yu L. 2013. Generic Development of Topical Dermatologic Products: Formulation Development, Process Development, and Testing of Topical Dermatologic Products. The AAPS Journal. 15(1):41-52. https://dx.doi.org/10.1208/s12248-012-94110

Chemat, F., Vian, M.A., Ravi, H.K., Khadhraoui, B., Hilali, S., Perino, S., Tixier, A.S.F. 2019. Review of Alternative Solvents for Green Extraction of Food and Natural Products: Panorama, Principles, Applications and Prospects. Molecules. 24(16):3007. https://dx.doi.org/10.3390/molecules241630 07 
Dantas, M.G.B., Reis, S.A.G.B., Damasceno, C.M.D., Rolim, L.A., Rolim-Neto, P.J., Carvalho, F.O., Quintans-Junior, L.J., Almeida, J.R.G.S. 2016. Development and Evaluation of Stability of a Gel Formulation Containing the Monoterpene Borneol. The Scientific World Journal. 2016:7394685. https://dx.doi.org/10.1155/2016/7394685

Daud, N.S., Akbar, A.J., Nurhikmah, E., Karmilah. 2018. Formulation of Snail Slime (Achatina Fulica) Anti-Acne Emulgel using Tween 80-Span 80 as Emulsifying and HPMC as Gelling Agent. Borneo Journal of Pharmacy. 1(2):64-67. https://doi.org/10.33084/bjop.v1i2.369

Fujiastuti, T., Sugihartini, N. 2015. Sifat Fisik dan Daya Iritasi Gel Ekstrak Etanol Herba Pegagan (Centella asiatica L.) dengan Variasi Jenis Gelling Agent. PHARMACY: Jurnal Farmasi Indonesia (Pharmaceutical Journal of Indonesia). 12(1):11-20.

Handayani, H., Sriherfyna, F.H., Yunianta, Y. 2016. Ekstraksi Antioksidan Daun Sirsak Metode Ultrasonic Bath (Kajian Rasio Bahan: Pelarut Dan Lama Ekstraksi). Jurnal Pangan dan Agroindustri. 4(1):262-272.

Marriott, J.F., Wilson, K.A., Langley, C.A., Belcher, D. 2010. Pharmaceutical Compounding and Dispensing. $2^{\text {nd }}$ Revised edition. London: Pharmaceutical Press.

Ministry of Health of the Republic of Indonesia. 1995. Farmakope Indonesia IV. Jakarta: Ministry of Health of the Republic of Indonesia.

Mulyanti, D., Rismawati, E., Maulana, I.T., Febriani, D., Dewi, Y.N. 2015. Uji Aktivitas Antibakteri Ekstrak Etanol Daun Sirsak (Annona muricata L.) pada Bakteri Propionibacterium acnes, Staphylococcus aureus, dan Staphylococcus epidermidis. In Prosiding SNaPP: Kesehatan (Kedokteran, Kebidanan, Keperawatan, Farmasi, Psikologi) (325-330). Universitas Islam Bandung, Bandung: Pusat Penerbitan Universitas (P2U) Unisba.

Otto, M. 2009. Staphylococcus epidermidis - the "accidental" pathogen. Nature Reviews Microbiology. $\quad$ 7(8):555-567. https://dx.doi.org/10.1038/nrmicro2182

Pai, B.H.M., Rajesh, G., Shenoy, R., Rao, A. 2016. Antimicrobial Efficacy of Soursop Leaf Extract
(Annona muricata) on Oral Pathogens: An Invitro Study. Journal of Clinical \& Diagnostic Research. 10(11):ZC01-ZC04. https://dx.doi.org/10.7860/JCDR/2016/183 29.8762

Pertiwi, R.D., Kristanto, J., Praptiwi, G.A. 2016. Uji Aktivitas Antibakteri Formulasi Gel untuk Sariawan Dari Ekstrak Daun Saga (Abrus precatorius Linn.) terhadap Bakteri Staphylococcus aureus. Jurnal Ilmiah Manuntung: Sains Farmasi dan Kesehatan. 2(2):239-247.

Prausnitz, M.R., Langer R. 2008. Transdermal drug delivery. Nature Biotechnology. 26(11):12611268. https://dx.doi.org/10.1038/nbt.1504

Purnamawati, S., Indrastuti, N., Danarti, R., Saefudin, T. 2017. The Role of Moisturizers in Addressing Various Kinds of Dermatitis: A Review. Clinical Medicine \& Research. 15(3-4):75-87. https://dx.doi.org/10.3121/cmr.2017.1363

Rowe, R.C., Sheskey, P.J., Quinn, M.E. 2009. Handbook of Pharmaceutical Excipients. $6^{\text {th }}$ Edition. London: Pharmaceutical Press.

Sayuti, N.A. 2015. Formulasi dan Uji Stabilitas Fisik Sediaan Gel Ekstrak Daun Ketepeng Cina (Cassia alata L.). Jurnal Kefarmasian Indonesia. 5(2):74-82.

http://dx.doi.org/10.22435/jki.v5i2.4401.7482

Yang, J.H., Yoon, J.Y., Kwon, H.H., Min, S., Moon, J., Suh, D.H. 2017. Seeking new acne treatment from natural products, devices and synthetic drug discovery.

Dermato-Endocrinology. 9(1):e1356520.

https://dx.doi.org/10.1080/19381980.2017.13 56520

Yang, K., Han, Q., Chen, B., Zheng, Y., Zhang, K., Li, Q., Wang, J. 2018. Antimicrobial hydrogels: promising materials for medical application. International Journal of Nanomedicine. 13:22172263.

https://dx.doi.org/10.2147/IJN.S154748 